\title{
Проблемы сохранения генофонда сосны обыкновенной в ленточных борах Прииртышья
}

\section{Problems of preservation of the gene pool of Pinus sylvestris in pine forests of Irtysh}

\author{
Чеботько Н. К. \\ Chebotko N. K. \\ Казахский НИИ лесного хозяйства и агролесомелиорачии, г. Щучинск, Казахстан e-mail: chebotkon@mail.ru \\ The Kazakh research Institute of Forestry and agroforestry, c. Shuchinsk, Kazakhstan
}

Peфepam. В статье приведены некоторые данные по отбору и изучению ценного генофонда сосны обыкновенной в ленточных борах Прииртышья. Выделены лесные генетические резерваты, плюсовые насаждения и плюсовые деревья. Проведены работы по созданию объектов постоянной лесосеменной базы сосны обыкновенной.

Ключевые слова. Сосна обыкновенная, ценный генофонд, ленточные боры, генетические резерваты, создание объектов.

Summary. The article presents some data on the selection and study of the valuable gene pool of Pinus sylvestris in the band forests of Irtysh. Forest genetic reserves, plus stands and plus trees have been revealed. Works on creation of objects of a constant forest seed base of Pinus sylvestris are carried out.

Key words. Belt forests, creation of objects, genetic reserves, Pinus sylvestris, valuable gene pool.

Проблеме сохранения генофонда придается огромное значение во всем мире, поскольку потеря одного гена или нескольких генных комплексов приведет к их безвозвратной утрате. Основной целью сохранения генофонда является охрана определенной части биологического разнообразия для будущих поколений человечества. Для сохранения генофонда Pinus sylvestris L. уникальных ленточных боров Прииртышья были организованы два государственных лесных природных резервата (ГЛПР) в Восточно-Казахстанской (ГЛПР «Семей орманы») и Павлодарской (ГЛПР «Ертіс орманы») областях. На территориях ГЛПР применяются две формы сохранения: in situ (консервация деревьев в естественных популяциях - заповедники, государственные национальные парки, генетические резерваты, плюсовые насаждения, плюсовые деревья и др.); ex situ (сохранение генов, генотипов в искусственных условиях клоновые архивы, лесосеменные плантации, постоянные лесосеменные участки, коллекции редких, исчезающих и ценных экзотов и др.).

Выделение лесных генетических резерватов сосны обыкновенной - одна из форм сохранения её генофонда в естественных условиях (in situ). В ГЛПР «Семей орманы» на 1 января 2017 г. выделено 1265 га, из них 590 га - в Бородулихинском филиале, Дмитриевском лесничестве, 675 га в Букебаевском филиале, Букебаевском лесничестве. В ГЛПР «Ертіс орманы» выделено 669 га - Шалдайский филиал, Садыкащинское лесничество. В лесных генетических резерватах запрещены все виды деятельности, за исключением сбора семян, пыльцы и черенков, проведения научных исследований. Выбор участков под резерваты проводился в естественных насаждениях сосны обыкновенной, не пройденных пожарами и сохранившимися уникальными деревьями (Данченко, Кабанова, 2004). Состояние деревьев в ГЛПР удовлетворительное, требуется проведение мероприятия на выделенной территории - очистку от лесосечной захламленности.

На территории ГЛПР «Ертіс орманы», в Шалдайском филиале подобраны 4 участка плюсовых насаждений сосны, три из которых находятся в Садыкащинском лесничестве с общей площадью 50,4 
га и один участок в Шалдайском лесничестве, площадью в 3 га. В результате селекционно-семеноводческой инвентаризации в 2012 г. подобраны еще 2 плюсовых насаждения сосны в Шалдайском филиале, Шалдайском лесничестве. Первое насаждение находится в квартале 59 , выделе 3 , общая площадь составляет 8,5 га, возраст 60 лет, II бонитет, тип условий произрастания - сухой сосняк, полнота 0,6. Средний диаметр деревьев - 19 см, высота - 18 м. Второй участок расположен в квартале 59 , выделе 8 и занимает площадь 6 га. Возраст деревьев 50 лет, полнота 0,7, II бонитет, тип условий произрастания сухой сосняк, средняя высота насаждения 16 м, средний диаметр 18 см. В ГЛПР «Семей орманы» плюсовые насаждения не подбирались.

Плюсовые деревья сосны отобраны в обоих ГЛПР. В ГЛПР «Семей орманы» отобрано всего 43 плюсовых деревьев, в том числе, 28 - в Бородулихинском филиале, Дмитриевском лесничестве, 8 деревьев - в Канонерском филиале, Джемурском лесничестве, по 2 дерева - в Букебаевском филиале, Букебаевском лесничестве и Новошульбинском филиале, Успенском лесничестве, по 1 дереву - в Букебаевском филиале: Ромадановском и Шадрухинском лесничествах, и Долонском филиале, Байдаулетском лесничестве. В ГЛПР «Ертіс орманы», в Шалдайском филиале всего отобрано 27 плюсовых деревьев сосны, в том числе, 20 - Садыкащинском лесничестве, по 2 дерева - Первомайском, Степном и Бауртальском лесничествах и 1 - Заводском лесничестве.

Отбор плюсовых насаждений и плюсовых деревьев проводится в Казахстане постоянно, в том числе в ГЛПР «Семей орманы» и «Ертіс орманы», однако, закладка опытных объектов по регионам не осуществляется: не заложены клоновые архивы и испытательные культуры потомств плюсовых деревьев. Теряется цель проводимых работ, которая направлена на сохранение генофонда сосны в искусственных условиях, проведение испытания потомства плюсовых деревьев и отбор перспективных клонов и полусибсового потомства для закладки лесосеменных плантаций.

Другой формой сохранения генофонда сосны обыкновенной является ex situ- создание постоянной лесосеменной базы (ПЛСБ). Создание ПЛСБ в Прииртышье имеет специфические особенности, которые обусловлены почвенно-климатическими условиями произрастания основных лесообразующих пород, слабой селекционной изученностью насаждений, разной интенсивностью ведения лесного хозяйства. Зональными для этого района являются боровые почвы. Боровые песчаные почвы формируются под пологом сосновых насаждений, имеют маломощную подстилку (2-3 см, реже 5 см), содержат незначительное количество гумуса (до 4\%), характеризуются хорошими лесорастительными условиями. На низких поверхностях внутри ленточных боров развиты луговые глубоковскипающие почвы, а в аналогичных условиях безлесных территорий - каштановые и лугово-каштановые почвы, часто в комплексе с солонцами. Солонцы встречаются и отдельными участками. Для лесовыращивания они непригодны. На лесонепригодных почвах создание ПЛСБ строго запрещено (Лесной кодекс РК, 2005).

Более подробно остановимся на создании ПЛСБ в ГЛПР «Ертіс орманы». В рамках Проекта по контракту CS/SS-08 в период 2010-2012 гг. выполнялась договорная тема «Формирование постоянной лесосеменной базы на территории государственного лесного фонда ГЛПР «Ертіс орманы» по бюджетной программе 044 «Сохранение лесов и увеличение лесистости территории республики», подпрограмме 016 «За счет финансирования внешних займов из республиканского бюджета» и подпрограмме 004 «За счет внешних займов» по специфике 149 «Прочие услуги и работы».

Создание постоянной лесосеменной базы предусматривает выполнение следующих целей (Ефимов, 1987; Бреусова и др., 1998; Лесной кодекс РК, 2005; Правила создания, формирования..., 2005):

- обеспечение производства селекционно-ценными семенами, использование которых позволит повысить продуктивность, устойчивость и качество создаваемых насаждений, сократить срок их выращивания;

- концентрацию семенных объектов в специализированных учреждениях - лесных селекционных центрах, производственных семеноводческих станциях;

- применение прогрессивной технологии, обеспечивающей непрерывное и рациональное производство генетически ценных семян.

В объекты ПЛСБ входят постоянные лесосеменные участки (ПЛСУ) и лесосеменные плантации (ЛСП), задачей которых является массовое получение ценных по наследственным свойствам и посевным качествам семян в течение длительного времени. Практически во всех странах мира с развитым лесным хозяйством основной формой организации семеноводства являются лесосеменные плантации 
(ЛСП), создаваемые путем вегетативного или семенного размножения, отобранных в насаждениях лучших по фенотипу, т.н. «плюсовых» деревьев. Создание лесосеменных плантаций представляет качественно новый этап, знаменующий переход от стихийного начала в семенозаготовках к системе мероприятий, направленных на регулярное и массовое производство ценных по наследственным свойствам семян, на концентрацию этих работ в специализированных хозяйствах.

Поскольку создание постоянной лесосеменной базы - дело общегосударственной важности, Казахским НИИ лесного хозяйства и агролесомелиорации была дана оценка состояния лесосеменной базы в ГЛПР «Семей орманы» и «Ертіс орманы», питомнического хозяйства, определена эффективность планирования и осуществления мероприятий по воспроизводству лесов и лесоразведению в гослесфонде природных резерватов, выявлены основные проблемы. Разработаны рекомендации по внедрению технологий по альтернативным методам воспроизводства лесов и лесоразведению, направленных на повышение приживаемости лесных культур, снижению количества посадочного материала на единицу площади посадки по сравнению с действующими нормативами, снижению расходов при выполнении мероприятий по воспроизводству лесов и лесоразведению (Кабанова, Данченко, 2016).

Проекты по созданию ЛСП были составлены согласно «Правил выявления, создания, аттестации и учета объектов селекционно-семеноводческого назначения на участках государственного лесного фонда», утвержденных приказом Председателя Комитета лесного и охотничьего хозяйства Министерства сельского хозяйства Республики Казахстан от 30 января 2007 года № 39 (далее - «Правила ...»). Освоение проектов по созданию ЛСП в ГЛПР «Ертіс орманы» запланировано с 2013 г., продолжительностью не менее 8 лет.

В Тайбогарском лесничестве Бескарагайского филиала в квартале 63, выделе 1 на площади 5 га был подобран участок под ЛСП. На этом участке почвы по механическому составу песчаные. По запасу питательных веществ эти почвы мало обеспечены, но все же являются достаточно пригодными для лесовыращивания. Весной 2011 г. была проведена посадка посадочного материала сосны с закрытой корневой системой (с комом земли) для создания ЛСП. Сеянцы брались на противопожарных разрывах рядом с местом проведения посадки. Обследованный участок представлен гарью 1998 г., рельеф слабо-волнистый. Очистка от порубочных остатков и захламленности проведена в 2010-2011 гг. По лесорастительным условиям - почвенным, гидрологическим, рельефу и экспозиции, он соответствует биологии проектируемых к выращиванию древесных и кустарниковых пород. Конфигурация участка обеспечивает эффективное использование машин и механизмов. При изучении почвы выявлено, что в ней достаточное содержание гумуса, общего азота и калия, но низкое содержание фосфора. Из анализа водной вытяжки видно, что почвы мало засолены, содержат незначительные количества солей, некарбонатные, не содержат гипса. Результаты измерения $\mathrm{pH}$ исследуемых почв варьируют от 5,60 до 7,60. Следовательно, известкование почв не требуется.

В августе 2012 г. на посаженных растениях была сделана прививка, черенки для прививки заготавливались с плюсовых деревьев, отобранных в Павлодарской области. Следовательно, шишки на привитом растении будут с хорошей наследственностью. Кроме того, и плодоносить привитое дерево начнет раньше, т.к. черенок сохраняет «генетическую память» возраста того растения, с которого срезан. На участке, предназначенном под создание ЛСП, было сделано 1093 прививки. Для прививки заготавливались черенки с лесосеменной плантации сосны, созданной в 1994 г. на территории питомника в Шалдайском филиале ГЛПР «Ертіс орманы» (для ЛСП использовались плюсовые деревья, занесенные в госреестр по Павлодарской области РК). Состояние плантации в период нарезки черенков удовлетворительное: привитые деревья имеют достаточно широкую крону и в большей части плодоносят.

Весной 2013 г. проведена инвентаризация прививки на подвойные культуры сосны и снятие обвязки с привитых растений в Тайбогарском лесничестве Бескарагайского филиала. Приживаемость прививок составила 43,6 \%. Прижившихся прививок было 476 шт. С прижившихся привитых растений была снята обвязка и подвой посажен на «шип», т.е. был удален прирост подвоя. Кроме того, удалены боковые побеги на подвое (Рекомендации по технологии прививок ..., 1970). В июле-августе 2013 г. повторно были выполнены прививки на те подвои, где погибли привойные черенки. Обследование привитых растений на ЛСП в 2015 г. показало, что почти все они прижились, имеют удовлетворительное состояние и хороший рост. 
За два года были подобраны участки ПЛСУ сосны на площади 92 га, из них 52 га в Бескарагайском филиале, 40 га - в Шалдайском филиале. ПЛСУ были отобраны в лесных культурах и естественном насаждении в возрасте 5-10 лет. Провели первый этап формирования постоянного лесосеменного участка в Шалдайском лесничестве на площади 40 га: вырублен каждый третий ряд лесных культур и проведено прореживание в загущенных рядах для увеличения площади питания семенных растений. Размещение деревьев на этих участках сформировали более редкое $-6 \times 8$ м, поэтому они имеют достаточно места для почвенного питания, крона у них раскидистая, освещенность ее высокая и, следовательно, урожайность семенных деревьев достаточно высокая. Кроме того, из-за редкого размещения на площади, возможен подъезд техники, что значительно упростит работу по сбору шишек.

Второй этап формирования ПЛСУ предусматривает вырубку еще одного ряда, а в оставшемся ряду оставляются семенные деревья, отобранные заранее, остальные убираются. Убрать сразу все деревья на участке, кроме семенных, нельзя, т.к. из-за резкого осветления и редкого расположения растения могут погибнуть. У семенных деревьев проведена декапитация кроны - т.е. удалена верхушка. Это сделано для того, чтобы ограничить рост привитых растений в высоту и увеличить размеры плодоносящей части кроны.

В последующие годы формирование ПЛСУ и уходные работы за объектами проводятся силами работников ГЛПР «Ертіс орманы». Проводимые мероприятия позволят создать на территории гослесфонда постоянную лесосеменную базу для сбора шишек и получения селекционно ценных семян сосны, используемых для воспроизводства ленточных боров Прииртышья.

Для сохранения генофонда природных резерватов необходимо проводить конкретные меры, которые заключаются в следующем:

- Создавать лесосеменную базу для лесовосстановления гарей прошлых лет генетически ценным материалом, т.е. семенами, собранными в лесных генетических резерватах, плюсовых насаждениях и с плюсовых деревьев.

- При создании ПЛСУ возможен отбор участков на гарях 3-5- летней давности при условии, что произрастающий рядом древостой относится к категории «нормального».

- В лесных генетических резерватах проводить те мероприятия, которые не обедняют генофонд (санитарные рубки, уборка зараженных и ветровальных деревьев). Разработать меры по содействию естественному возобновлению. Полностью запретить сенокошение и пастьбу скота. Сенокошение допускается лесной охраной в тех местах, где отсутствует естественное возобновление. На подъездных дорогах к резерватам установить аншлаги, запрещающие автотранспорту въезд на территорию резерватов и посещение туристами и местными жителями в любое время года.

Проблема сохранения биоразнообразия в лесах Казахстана представляет собой часть общей проблемы охраны окружающей среды и неразрывно связана с задачей рационального природопользования, поддержания равновесия в растительном мире и сохранения его неповторимого многообразия для будущих потомков.

\section{ЛИТЕРАТУРА}

Бреусова А. И., Мосин В. И., Чеботько Н. К. Принципы подбора родительских пар для гибридно-семенных плантаций сосны // Информационный листок. - Кокшетау, 1998. - № 98-120. - 7 с.

Данченко М. А., Кабанова С. A. Особо охраняемые природные территории Республики Казахстан и проблемы их сохранения // Актуальные проблемы лесного комплекса, 2004. - № 9. - С. 86-88.

Ефимов Ю. П. Семеношение и рост сосны на плантациях вегетативного и семенного происхождения // Лесное хозяйство. - 1987. - № 12. - С. 38-41.

Кабанова C. A., Данченко М. $\boldsymbol{A}$. Результаты изучения влияния сроков посадки на состояние и рост лесных культур сосны обыкновенной (Pinus sylvestris L.) в ленточных борах Прииртышья (на примере государственного лесного природного резервата «Ертіс орманы») //Вестник Алтайского государственного аграрного университета. 2016. - № 7 (141). - С. 47-51.

Лесной кодекс Республики Казахстан. - Алматы, 2005. - 72 с.

Правила создания, формирования, эксплуатации ПЛСБ основных лесообразующих пород на селекционной основе. - Бастау, Алматы, 2005. -5 с.

Рекомендации по технологии прививок сосны и уходу за ними в лесхозах Северного Казахстана. - Алма-Ата, 1970. $-27 \mathrm{c}$. 